\title{
Organizing in the age of systems: Ivan Illich's critical contributions to organization studies
}

\author{
LUCAS CASAgRANDE ${ }^{1}$ \\ Nilo Coradini de Freitas ${ }^{2}$ \\ ${ }^{1}$ Universidade federal do Rio Grande do Sul (UFRGS) / Escola de AdMinistração, Porto Alegre - RS, Brazil \\ 2 Universidade Federal do Rio Grande do Sul (UFRGS) / Programa de Pós-GraduaÇão em Administração, Porto Alegre - RS, BRAZIL
}

\begin{abstract}
This essay presents Ivan Illich's critique of institutionalization in modern society and its evolution to the Age of Systems, the problems that arise, and its imbrication with technological choices. The essay explores the author's thoughts and the contributions of his dialogues to the Organization Studies. The study presents the idea of institutional imbalance and correlates it with the concept of manipulative tools as opposed to convivial tools, assuming, therefore, that technique is not something neutral. The study then discusses how industrial society reifies the human being and becomes a great functional social system, a 'body with organs,' which needs the institutions 'school,' 'health', and industry. Industrial society creates disabling professions that specialize individuals until their full alienation and mediation, and it incorporates a system of mass surveillance in the subjectivity of each one. Against this, different propositions of withdrawing power, or deconstructing rules are possible, as shown by Giorgio Agamben.
\end{abstract}

Keywords: Ivan Illich. Conviviality. Age of Systems. Alternative Organizations. Institutionalization.

\section{Organizar na era dos sistemas: as contribuições críticas de Ivan Illich aos estudos organizacionais}

\section{Resumo}

Este artigo apresenta a crítica de Ivan Illich à institucionalização na sociedade moderna, seu desenrolar na era dos sistemas e os problemas dela decorrentes por conta de suas escolhas tecnológicas. O objetivo é apresentar o pensamento do autor e suas contribuições aos estudos organizacionais. Para tal, adotou-se um formato ensaístico, visando a demonstrar as contribuições do autor e seus possíveis diálogos com a área. Assim, apresenta-se a ideia de desequilíbrio institucional, correlacionando-a com o conceito de ferramentas manipulativas em oposição a ferramentas conviviais. Nesse sentido, assume-se a técnica como não sendo neutra. Em seguida, aborda-se como a sociedade industrial reifica o ser humano e, nesse processo, transforma-se em um grande sistema social funcional, um corpo com órgãos, necessitando das instituições escola e saúde, além da indústria. Ela cria profissões incapacitantes que especializam os indivíduos até sua plena alienação e mediação. Por fim, incorpora um sistema de vigilância em massa na subjetividade de cada um. Diante disso, diferentes proposições são possíveis, como em Giorgio Agamben, de retirar o poder e desconstituir regras.

Palavras-chave: Ivan Illich. Convivialidade. Era dos sistemas. Organizações alternativas. Desinstitucionalização.

\section{Organizar en la Era de los Sistemas: Contribuciones críticas de Iván Illich a los Estudios Organizacionales}

\section{Resumen}

El artículo presenta la crítica de Ivan Illich a la institucionalización en la sociedad moderna y su desarrollo en la Era de los Sistemas y los problemas derivados de ésta debido a las elecciones tecnológicas. Se pretende presentar el pensamiento del autor y sus contribuciones al área de Estudios Organizacionales. Para ello, se adoptó un formato ensayístico, buscando demostrar las contribuciones del autor y sus posibles diálogos con el área. Así, se presenta la idea de desequilibrio institucional y se la correlaciona con el concepto de herramientas manipulativas en oposición a herramientas convivenciales. Para tal, se asume la técnica como no siendo neutra. A continuación, se aborda cómo la sociedad industrial reifica al ser humano y, en ese proceso, se transforma en un gran sistema social funcional, en un cuerpo con órganos, para lo que necesita las instituciones escuela, salud e industria. Crea profesiones incapacitantes que especializan a los individuos hasta su plena alienación y mediación. Finalmente, incorpora un sistema de vigilancia masiva en la subjetividad de cada uno. Frente a eso, son posibles diferentes proposiciones, como en Giorgio Agamben, de retirar el poder y suprimir reglas.

Palabras clave: Ivan Illich. Convivencialidad. Era de los Sistemas. Organizaciones alternativas. Desinstitucionalización. 
This crisis is rooted in a major twofold experiment which has failed, and I claim that the solution of the crisis begins with a recognition of the failure. For a hundred years we have tried to make machines work for men and to school men for life in their service. Now it turns out that machines do not work and that people cannot be schooled for a life at the service of machines. The hypothesis on which the experiment was built must now be discarded (ILLICH, 1973a, p. 23).

\section{INTRODUCTION}

It was a joyful night at the Canadian ambassador's house in Iran. At the dinner table were the then ambassador James George, Peter Lamborn Wilson, and Ivan Illich. The national context in 1974 was of a liberal rule preceding the Iranian religious revolution. A telegram arrived, written by the recently elected governor of California, Jerry Brown, addressed to Ivan Illich. By reading the mail, Illich, whose calm temper gave him the aura of a saint, started cursing with anger. This behavior would already be enough to leave the ones present wondering, but the content of the telegram made the whole thing even stranger (BEY, 2008).

It just so happened that the telegram was an invitation for Ivan Illich to go to California and join the State's administration at a high-level office. Along with it was an invitation to be on TV, offering a public-friendly face to government policies, and to fly to the United States on Jerry Brown's nickel. The tablemates, in a daze, asked Illich to explain the reasons for his fury. What happened was: a) Illich hated flying and only went to Tehran because the invitation letter from his dinner companions was "full of typing errors"1; b) Illich didn't think media was an institution subject to reform because, by definition, it made objective what is inherently subjective; and c) he did not wish to reform the State and its institutions, but to see them fall on the face of other forms of organization - so being a part of the administration of the State of California was something absurd and contrary to his convictions (BEY, 2008).

But his rage originated from the fact that his subjectivity, famously linked to the counterculture movement, was under attack, an attempt of cooptation. In fact, to Illich, it would not be possible to solve problems by making the State more open. As the problem of education, for instance, the issue is not about school inefficiency, elitism, or, as in Paulo Freire (1987), a pedagogy that sees the student as the client of a service in which he or she must be passive. The problem was that school, a "sacred cow" of both the political left and right wings, was (and is) a tool of social hierarchization and for domination, linked to developmentalism that preaches economic growth as the ultimate way to escape social conflicts. The modern school is, by definition, a tool for a project of exploiting nature and people.

In this paper, we aim to show how Illich's thought is vast and how his oeuvre has the potential to offer a better understanding of the relations among organizations, society, and technique. Illich wrote, throughout his life, about institutions that, like school, begin (or began) to self-perpetuate, to answer to their own needs, rather than the purposes to which they were created in the first place. Illich's thought constitutes a rich source, exposing a perspective for the connections among technology, authority, and institutions; and of these in the different possibilities of organizational arrangements and social equity. He saw how the use of different tools would foster different social relations and, with them, different subjectivities. Starting from this theoretical milestone, we continue to address the critique of industrialism and development. The industrial way of life undermines people's capacity to conceive their needs outside the frame of demands for industrial products. At the same time, such products will never be able to fulfill everyone's needs, as new necessities never stop being created, blocking the capacity for solving problems differently. According to Illich, our age creates homo miserabilis, the person who became so alienated and mediated by the industrial society that his or her life gets caught in a never-ending cycle of need creation and fulfillment.

From this introduction, we will address the critique of Prometheism that is inherent to bureaucratic organizations. According to Illich, technical discourse present in modern scientism, which is the basis for bureaucracy, shows itself to be naive for believing in achieving human freedom through subjection to machines. In fact, the author realized that the contrary is what

${ }^{1}$ Besides anecdotical, Illich's fear was not a mere phobia. As the author shows in "Energy and Equity" (ILLICH, 2005), the intensive use of energy makes social equity impossible. The high speeds under which a portion of society travels originates from spatial distortion, the transformation of social conviviality into infrastructure for high speeds. 
really happened in the modern experiment, through what he named manipulative tools. This way, we will address the idea of institutional imbalance and the author's notion of tool.

After establishing this theoretical basis, we shall address the institutions Illich has devoted himself to criticize: institutionalized education, health, and work. To do that, we sought his publications related to education to show how it is nothing but a tool of developmentalism. Even though Illich and Paulo Freire were good friends and held a partnership, their thoughts are, at times, antagonistic. In the medical field, Illich reported how institutionalization delegated the body to the professional, the physician. Autonomy was lost, and an enormous cost was created favoring a technique that brought fewer benefits to life than one would think. The same logic happened at work: modern society has transformed creative activities into disabling work, the production of novelty into sameness reproduction.

Such reproduction as time goes by gets a tone of introjection of social roles. That which was at first assigned by modern institutions began to, gradually, become introjected into subjects. This rupture between institution and system marks a rupture in Ivan Illich's thought around the 1980s when he turns from focusing on modern institutions to concentrating on the introjection of society's cybernetic roles into individuals. This way, life is reduced into a function, creativity into disabling work, and social relations into the social system. All of that being mediated by manipulative tools, by modern technique, and by bureaucracy. This is what the author called the Age of Systems.

Furthermore, we summarize, initially, the author's alternatives. Convivial tools, a celebration of life, and Epimetheanism in opposition to the Promethean stance (as love for the technique itself). We conclude that Ivan Illich's oeuvre offers important contributions to organization studies and allows for dialogues with many authors of the field, with the potential to corroborate and deepen already existent reflections.

\section{INSTITUTIONAL IMBALANCE AND THE NOTION OF TOOL IN IVAN ILLICH}

In the same way that iatrogenesis (the disease created by the medical intervention) constitutes a problem widely overlooked in modern society, the use of tools that don't solve the problems they should and, at the same time, create new ones isn't usually considered. Such a consideration is not unusual, but it is necessary to establish it on a large scale. The ancient Greeks told the story of Prometheus, a titan who stole the tools (the "fire") of the Olympian gods to distribute them to human beings. As an ironic sentence for his crime, this titan - an immortal being - was condemned to have his liver devoured every day by a huge eagle. His immortal liver would be new the next day - but his punishment would be repeated. The titan's horrible penalty can be interpreted as an appropriate punishment for the evil it caused: it enabled human beings to obtain tools that, when used to solve old problems, would generate new ones, eternally.

For Illich, a premise made possible the advancement of industrial solutions: that it would be possible to replace slaves with machines. However, this premise proved to be false. The attempt to develop solutions on these bases led to the hypertrophy of bureaucratic devices that shaped the world to its dimensions, in detriment of human dimensions, causing strangeness to people and dependence on such devices. Most social agencies reorganized by science have gone through this process.

At first, new knowledge is applied to the solution of a clearly stated problem and scientific measuring sticks are applied to account for the new efficiency. But at a second point, the progress demonstrated in a previous achievement is used as a rationale for the exploitation of society as a whole in the service of a value which is determined and constantly revised by an element of society, by one of its self-certifying professional Elites (ILLICH, 1973a, p.7).

Illich's thinking is guided by a central category: the tool. This concept, synonymous with what many authors call technology, is a concept of modern mental topography that establishes a means by which human beings try to achieve their goals. In other words, a tool is the modern concept that encompasses the means to express human intentions, whatever they may be. Such a notion, put in this broad way, makes it possible to cover not only equipment but also organizations. 
Tools can be divided into two categories, as the author proposes: a) hand tools ${ }^{2}$; or b) power tools ${ }^{3}$. The first are those that adapt a person's energy for a specific task, such as a pen, hammer, knife, pulleys, or for more complex tasks, such as a handloom or a bicycle. Hand tools can also be very sophisticated, such as a cycle path system with repair stations used by bicycles and rickshaws. The manipulative (or power) tools, on the other hand, require energy external to the human being. It may be the ox that plows the land, the horse on which it is saddled or more complex tools, such as the automobile and, still, things that we treat today as trivial - everything we plug in a power outlet.

The prevalence of hand tools, those that do not require external energy other than the human body's, allows for the inhabitants of a given community to act more creatively. In such situations, the tools are convivial. The opposite relation, typical of industrial modernity, produces domination of the power tools, that subjugate the hand tools. In this situation, the tools are manipulative. In short, a higher intensity of power tools produces a relation of technical domination over hand tools, manipulating them and, altogether, the people that use the hand tools. In the end, in this domination process, the man that handles tools becomes an ox that pulls the plow for others.

Illich's tool typology generates, as a consequence, two production spheres: a) an autonomous one; and b) a heteronomous one. The autonomous sphere is the one where material production has a prevalence of hand tools. A heteronomous sphere is the one that operates through the division, and specialization of labor and of producers and consumers. It operates through markets and requires a complex apparatus of institutions to train, enforce, and supervise specialists. In the end, each of which operates a pre-established universe of social production and the horizontal division of labor, through specialists, ends up requiring a vertical division of labor, through ruling and concentration of the means of production, that is, of tools.

Each of the industrial products is a result of a form of production that is expensive in invested capital, be it in terms of material or knowledge. "Each of these products competes with a use value that people have always enjoyed autonomously" (ILLICH, 1975a, p. 66, our translation). Goods produced autonomously are, by their nature, impossible to be alienated into a market, manufactured for sale, do not show on the GNP, and, most of the time, are not activities made for money nor could they be. The author sought to study the strangulation of the autonomous mode of production through the advancement of the heteronomous, without demonizing industrialism: "no doubt industrial product can make action more effective and the actor more independent. It is the case of bicycles, of books and antibiotics, that besides that can be produced more effectively in an industrial manner" (ILLICH, 1975a, p.68, our translation). Therefore, synergy is possible between both modes of production is presented. However, an imbalance favoring the heteronomous form is perceived, that leads the production into counterproductivity, once it exceeds a certain threshold. The said threshold appears when progress previously obtained is converted into a means of exploiting the whole of society in service of a specialized élite 4 .

Institutional imbalance is fostered by the advancement of bureaucratic and industrial institutions, resulting from the prominence of the heteronomous sphere of production. Illich (1973a) saw this process as harmful for six reasons:

1) Biological degradation;

2) Radical monopoly;

3) Overprogramming;

4) Polarization;

5) Obsolescence; and

6) Frustration.

\footnotetext{
${ }^{2}$ Hand tools is the term used in the English language version (ILLICH, 1973a), which is the original version. However, this concept is slightly different in Latin languages. Illich, who spoke many languages, also wrote his books in many languages. The referred title, "Tools for Conviviality" (ILLICH, 1973a), in English; or "La Convivialité" (ILLICH, 1973b), in French; was written directly, at least in these two languages. In the later version, the concept is deemed "outil maniable," translated into Italian as "strumento maneggiabile" (ILLICH, 1974c) and to Spanish as "herramienta manejable" (ILLICH, 1974b), which sounds more consistent with the chosen Portuguese words for the term: "ferramenta manejável." However, the English version, written directly by the author, shows a small difference.

${ }^{3}$ As the concept discussed previously, the English version diverges from the Latin language variants. But here, the difference is more relevant. Illich used "power tools" in English, but used concepts that could be translated as "manipulative" in the Latin variants. The concept is featured in the original French version as "outil manipulable," translated from there to the Italian "strumento manipolabile," and to the Spanish "herramienta manipulable." In Portuguese it appears as "ferramentas manipuláveis" (ILLICH, 1976).

${ }^{4}$ Said threshold is the moment where manipulative tools become dominant as means to ends, triggering a process of continuous tautological specialization, when "the marginal utility of further professionalization declined, at least insofar as it can be expressed in terms of the physical well-being of the largest number of people" (ILLICH, 1973a, p. 16).
} 
The author understood that the use of technology could make the environment uninhabitable, which was already a truism in the 1970s. Radical monopoly is not that of a given enterprise to a particular market, but the exclusive character of a given industrial solution to a human need, excluding non-industrial ones. For instance, a city designed around the individual automobile can offer this product a radical monopoly, impeding other forms of transport to be effectively put to practice.

Overprogramming is the discrepancy in people's learning in which programmed knowledge - typical of schooling - stands out from knowledge developed from observation and participation. In an overprogrammed world, reality induces acceptable and unacceptable behaviors, as in a behavioralist hospice, where everyone is constantly "taught, socialized, normalized, tested, and reformed" (ILLICH, 1973a, p. 83). Such programming conditions individuals to deny their own senses in favor of a norm, of "truth," of science, of enunciative authority. Overprogramming is what, in Marcuse's (1991) terms, unidimensionalizes men into a single way of dealing with reality. Illich (1973a), in clear dialogue with Herbert Marcuse, points out that, in order to multidimensionalize, it is necessary to consider the six points mentioned above.

Similarly, Guerreiro Ramos (1989) realized that the behavioralist syndrome reduces the legitimacy of any thought and actions to its utilitarian conformity before the behavior and ruling of others. Polarization occurs with the development of the mega machines, to the extent that it imposes itself in people's everyday lives and requires trained elites to manage them, making an equitable distribution of power impossible. The idea of isonomy is referred to in the oeuvre of Guerreiro Ramos (1989, p. 150, our translation) as a solution to such a problem, which would constitute a "context in which the members [of a community] are equal." This idea, the author acknowledges, is inspired in previous authors, as Ivan Illich himself, who proposed "tools needed to social reconstruction, that Illich deemed 'convivial'" (GUERREIRO RAMOS, 1989, p. 151, our translation).

Finally, obsolescence is the concept that refers to the necessity of constant renewal of products required to the functioning of bureaucracies and society under their yoke, like cogs, machines, and diplomas. In each of these dimensions, tools can make it impossible for people to relate to or act in the environment surrounding them, which generates frustration.

Managerialism is a part of this process, spreading the idea that formal bureaucratic organizations, being the most efficient, are the best way to achieve organizational goals. This shaped organization studies as an applied social science - as positivism and science had become more powerful in the decades of 1950 and 1960 (MARSDEN and TOWNLEY, 2001).

Managerialism can be seen as an approach to the problem of governance that naturalizes capitalist relations as inevitable through a combination of ideology and technocracy. It fosters a progressive account of the modern world, based on the promises of technology, choice, abundance, and wealth (PARKER, 2018).

Illichian critique also unfolded to approach so-called "development." Latouche (2012, p. 4-5, our translation) emphasizes that

[...] all of Illich's oeuvre consists in challenging development, economic growth, industrialization and its heteronomous technique and the modern way of life, though he never presents the critique as a frontal attack, but through an analysis of institutions and their transformations.

To Illich (1977b), underdevelopment consists of having ever more people with ever fewer choices. It is a two-fold process of population growth and industrialization referenced from the so-called developed nations. Illich saw the rich nations transforming their war machines into development programs to the so-called Third World, as a way of "pacifying" it economically. Massive institutions producing expensive services dominate the horizons of our ingenuity:

The more the citizen is trained in the consumption of packaged goods and services, the less effective he seems to become in shaping his environment. His energies and finances are consumed in procuring ever newer models of his staples, and the environment becomes a by-product of his own consumption habits (ILLICH, 1977b, p. 56).

Developed nations "benevolently" imposed their straitjacket of car jams, hospital confinements, and classrooms to poor nations and named it, through international agreement, "development" (ILLICH, 1977b). "The population explosion overwhelms the imagination, but the progressive atrophy of social imagination is rationalized as an increase of choice 
between brands." (ILLICH, 1977b, p. 59). Both processes converge to produce more consumers, as imaginations become incapable of finding different solutions from the industrial ones to their needs. The use of managerialism is evidenced, for instance, in Development Administration and Management (DAM), adopted by international agencies such as the World Bank as a tool in the intervention promoted by rich nations in the so-called Third World, promoting a particular neoliberal economic order (COOKE, 2004).

Illich also posited underdevelopment as a "state of spirit" or a form of conscience in which it is only possible to imagine solutions that are impossible to be reached by the majority of people. That happens through reification (Verdinglichung): the perception of actual necessities transformed, hardened, into the demand for mass-produced merchandise. "This kind of reification occurs in the manipulation of primary human needs by vast bureaucratic organizations which have succeeded in dominating the imagination of potential consumers." (ILLICH, 1977b, p. 60). In this process, managerialism attributes necessities to human beings through an analytic tool called "organizational behavior," positing that people "calculate their preferences and make decisions about action accordingly," very similarly to homo oeconomicus that Parker (2018, p. 35) calls rational egoists. This way, vernacular is lost along with autonomy as necessities are manufactured, which are continuing and necessarily frustrated. Counterproductivity's general principle was explored in-depth theoretically in the realms of education, health and work, which we comment in the following sections.

\section{BODY WITH ORGANS: FROM DEPENDENCY OF INSTITUTIONS TO CYBERNETICS}

Illich's work allows us to glean that modern society is a project of domination under the pretense of functionality and productivism put forward through manipulative tools. Under the argument of greater efficiency, nature and human beings themselves are enslaved. In order to do that, it is necessary to create specialized armies, professionals capable of carrying out their tasks, even if small and specific. With this, the social system receives a sense of efficiency, and under these pretenses, specialized professional practices are legitimized, making people dependent upon such specialists.

Such a supposedly efficient process of specialization and work attribution, on the one hand, grants life itself to professionals and, on the other, puts everyone into a project of total professionalism. We become organs that interact in a big social body, as in Durkheim's (1977) metaphor, in which human life becomes a part of the social system, where the later has primacy over the earlier. This body with organs needs a series of institutional processes of reification of the human body, such as the school, the hospital, and industry, as we shall see in the following.

\section{Deinstitutionalizing education}

The title of Illich's most famous book recently republished in Brazil by Editora Vozes (ILLICH, 2018), Deschooling Society, is, by itself, provocative ${ }^{5}$. It is a claim for abandoning the idea that the school, as an institution, solves social problems. That is the transposition of the notion that education (as a substantive value) would emancipate humanity. Illich notes that there is a profound gap between school and education: to institutionalize something is not to make it omnipresent and may make it into a set of rules that turns means into ends. Otherwise, notice how the Judiciary appropriates itself of the value of "justice" on behalf of its own legitimacy - Judicial power itself became, in its newspeak ${ }^{6}$ into Justice itself. Indeed, the same happens with education: to educate oneself is a different thing from being taught.

His critique is echoed by recognized authors of organization studies in Brazil, such as Mauricio Tragtenberg (2002, p. 2, our translation): "Within Education faculties, the technocratic planner is trained, to whom it is important to discuss the means of education without discussing its ends, to manufacture structural forms that in reality are true 'restorations'."

Illich (1975b) highlights that the school, as a 'sacred cow,' is the institution that substitutes the Church in current times. We replace the rites of passage (baptism, communion, chrism, etc.) for diplomas and certificates. And as the wicked ones that

\footnotetext{
${ }^{5}$ In its Portuguese version, there is a debate regarding the exact title of the book according to different editions. Editora Vozes has published it in the Portuguese language as "Sociedade Sem Escolas" (School-less society), from the French version (Une Société Sans École). In contrast, Editora Deriva has published its translation as "Sociedade Desescolarizada" (ILLICH, 2007), from the original English (Deschooling Society).

${ }^{6}$ Reference to George Orwell's 1984 (2010).
} 
attend church to substitute ethics for institutional forgiveness, the school has become the one that blesses the ignorant, the unethical, and the suppressors of the life of others, as long as they comply with the formal scholarly requirements.

It is difficult, obviously, to get an education from a school that refuses to educate without requiring that its students submit simultaneously to custodial care, sterile competition, and indoctrination. It is difficult, obviously, to finance a teacher who is at the same time regarded as guardian, umpire, counselor, and curriculum manager. It is uneconomical to combine these functions in one institution. It is precisely the fusion of these four functions, frequently antithetical, which raises the cost of education acquired in school. This is also the source of our chronic shortage of educational resources ${ }^{7}$ (ILLICH, 1975b, p. 108).

Even though Illich and Paulo Freire have had their theoretic disagreements, they both shared a profound respect for each other. So much that Paulo Freire went several times to Cuernavaca, where Illich had worked (SILVA, 2016), as well as Illich had come a few times to Brazil (ILLICH, 1975c), including one visit with the reason of "obtain the extrication [...] of Paulo Freire" after the Brazilian coup d'Etat of 1964 (MILANA, 2008, p. 133, our translation). According to Mesquida (2007), both contemporary authors started from a theoretical and practical concern for the oppression of the Latin-American peoples. Despite their disagreements, they identified each other as peers on the same side of a battlefield. Moreover, as Estimado and Santos (2014) highlight, Illich was not, in fact, arguing for the end of schools, but for the end of the scholar institution's place as a guide for human life. We should transform education into a human instrument - and not the other way around. Such a distinction is subtle, and yet essential in Illich's debate: we certainly need spaces to produce and disseminate knowledge. But such places cannot be run by technocrats, nor can they be reduced to curricula, work shifts, attributions, workloads, so on and so forth. In the end, this is more than counterproductive: this is subversion, in the worst sense of the word, of a value into a set of rules.

This way, Illich and Freire concurred that institutions, as they were, caused more harm than good to society. Freire (1980, p. 7, our translation) affirms that as an "institution in itself, as something that has an unchangeable nature that can be deemed good, or bad, [...] the school does not exist, the school is being, historically." While Freire placed the school as a social subsystem subjugated to the dominant classes, but which, however, could be reformed to produce the opposite historical movement, Illich went further in his criticism, abandoning the idea of reforming the institution. He noticed that all scholar institution has as the definition of its modus operandi the processes of social selection and exclusion. In fact, few of those who attend schools apprehend what is there presented to them. There is also, as Illich noticed, an ideological factor of selection; as for Paulo Freire, he subverted that ideological factor, transforming bourgeois technicism into a politics of the oppressed. Illich, however, noticed that there was something special about that, but also realized that the process of selection and exclusion persisted, this time against the portion of the public that was unwilling to debate, think about the community or promote collective improvements:

I will never forget an evening with Freire's pupils, hungry peasants in Sergipe, in early 1964. One man got up, struggled for words and finally put into one utterance the argument I want to make in this article: "I could not sleep last night... because last evening I wrote my name... and I understood that I am I... this means that we are responsible" (ILLICH, 1975b, p. 124).

Like this, Illich concluded, if the institution survives, may it at least be shaped to become responsible for its peers. Should the school exist, may it be political and come from the desires of its members. In this manner, maybe one day, its subversion will allow us to overcome it. Perhaps we will cease to be humans with needs met by institutions and their techno-bureaucrats and become complete beings, situationists-generalists (as Debord (2011) names it). In other words, that we may become at the same time our artists, technicians, painters, and physicians and be self-taught. For now, the separated training of each profession structures society to disabling work.

\footnotetext{
"Let us not confuse here Illichian critique for an appeal to (neo)liberal austerity or to combat "cultural Marxism" (sic). As far as "deschooling" goes, they do in the sense of abolishing grades, for instance, like José Pacheco's Escola da Ponte. We can also find historical examples in experiences linked to the libertarian (in the European sense of the word) left, such as Sébastien Faure's La Ruche (2015) and Liev Tolstoy's lasnaia Poliana (see CODELLO, 2007). See also Illich (1990) and the documentary "Being and Becoming" (SER E VIR A SER, 2015).
} 


\section{Disabling work}

Illich has pointed out that modern institutions, as a part of a project, after trespassing a particular watershed, become harmful to society and lead people into becoming dependent on their (dis)services. From this, he deemed our historical moment as the "age of disabling professions," that is characterized by a society that mediates life and alienates work, making any project of autonomy impossible. In this kind of life, we substitute politics for specialists and our will for technocrats. We, ourselves, become technocrats. To do so, we must live a third of our lives locked into school systems that separate the body of knowledge and instill needs shaped by others into us. After this third fraction of life, we spend the following two thirds not only producing but also augmenting our own productivity. In this sense, the individual is subject to oligarchical monopolist interests, and economic growth is supported by the exploration of humans and nature (ILLICH, 1977a).

Illich bases his argument on the insight that modern society, despite having a range of available technological tools, uses its technique as a way of exploiting work evermore. The dream that spread in the first half of the 20th century that, with time, we would work less and less and would have more free time became a bitter reality. Instead of this liberating oneirism, we deal with a reality that transforms the whole of human activity into work, every creative act into an act of conformity. Notice current urban life: even the cooking and eating acts were reduced to work. Instead of families eating in their houses, we see the rise of the act of eating as the result of a provided service.

But that's not all. If, on the one hand, the urban proletarian classes work less and less in industries (and if rural work diminishes as well), on the other hand, new administrative procedures are created more and more. Yesterday's view of cities full of proletarians wearing their industrial overalls gives room to seas of people going in and out of offices, where they will spend their days producing paperwork, answering e-mails and telephone calls, following norms and procedures, and so on. That is what David Graeber (2018) names bullshit jobs: the "active" telemarketing workers, the attorneys of futile processes, the unmotivated managers of other unmotivated motivation specialists, the public relations professionals that only find silver linings, financial sector workers, administrative personnel that create layers of futile bureaucracy, and so forth. Most of these jobs do not produce, effectively, anything - other than the very continuity of work. Besides that, for example, a legal process requires judges, prosecutors, other attorneys, experts, etc.; a company's advertising requires an answer from its competition; administrative rules need more and more people to be fulfilled, and the list goes on and on (GRAEBER, 2018).

The irony of this state of affairs is that, as any liberal economist would notice, every economic relation should tend to maximize efficiency - yet, what happens is the very opposite. How can a capitalist system make people produce ever more irrelevant things? The answer, as Graeber (2018) notices it, is not economic, but moral and political. Capitalism is a project of domination and, as such, does not seek productivity for its own sake. Productivity and material wealth, central to any liberal discourse at least ever since Adam Smith, is a discourse that aims an external end. The author argues that the dominant classes realized that a happy and productive population, with free time in its hands, constitutes a threat, which makes work as a value on its own extraordinarily convenient for them.

Graeber (2018) realized, as did Illich, that the ruling classes have put forward a project of making the population so busy that it is impossible to revolt. For the author, this project started, with less strength, from the 1960s on. It was an answer to counterculture and to non-conforming movements - civil rights in the USA, May of 68 in France. In fact, Graeber (2018) has noticed that protestant ethics, as a set of values that praises work in itself, shows itself to be incredibly useful to the ruling classes, that started to exploit it to exhaustion. It became the dominant morality to believe that the one that doesn't work himself to death deserves the worst of destinies - we became slaves of our own belief in the virtue of work.

As we do in Illich, about underdevelopment as a state of spirit and about reification, in Graeber (2018), we also find a characterization of the current state of affairs as articulations with manipulative ends. Objectification of people occurs, through their transformation into consumers-specialists, culminating in homo miserabilis (ILLICH, 1996), practically an ideal opposite of situationist man. In the apex of this project, in the present moment, we reify our own bodies, granting them to specialists that know better of them than we do ourselves. Like this, the transformations of the notion of health take on a fundamental role, through a specific bodily formation. 


\section{Ealths' nemesis, the body's tantalum}

\section{When my health is at stake, Ultrafarma runs the game! (ULTRAFARMA, 2018, our translation).}

The above citation, from a piece of advertising that ran on Brazilian broadcast television, starred by Dunga, former football player and coach of the Brazilian national football team, shows the mundaneness with which the granting of the body came to occur. Published originally in 1975, Medical Nemesis: The Expropriation of Health (on later editions renamed as Limits to Medicine) is a central work by Ivan Illich in which he shows how two great forces compose the social sphere - institutions and the body - and how they struggle with each other, the first one being the winner in an industrial society. Health, a typical property of the body and autonomous belonging to each human being, is instrumentalized in favor of an institution. In this way, the central argument is that the medical establishment became dangerous to health. Dependency upon the health professional destroys social relations, constituting what Illich named "the medicalization of life." Such medicalization is the acting of industrial technologies in what matters the most in the human sphere: the body. In this sense, modern medicine, through its institutions, produces a radical monopoly of the use of medical apparatus at the expense of the body's autonomy. In the end, "The medical and para-medical monopoly [...] is a glaring example of the political misuse of scientific achievements to strengthen industrial rather than personal growth" (ILLICH, 1975a, p. II, our translation).

To strengthen his argument, Illich attacks in three fronts: a) in the first one, he shows that what we consider, in modernity, as medical achievements are, actually, achievements that could be attributed to other sources (such as the enhancement in nurturing, hygiene and, more evidently, sanitation); b) in the second one, he shows how institutionalized health destroys social relations; and c) in the third one, he argues that the body is not measurable and that, when we do measure it, we take away its autonomy (ILLICH, 1975a). Deriving from the first one, clinical iatrogenesis is created, when unnecessary health procedures are charged to subjects and cause, frequently, more trouble than they solve. Deriving from the second one, there is the concept of social iatrogenesis, which makes the subject, and his social relations, into a passive being facing an alleged technical superiority of medicine. Social iatrogenesis also creates the category of the ill, with all of its social consequences. And third, we have structural iatrogenesis, that is, the substitution of autonomous values for the medical institution's technical values. The cultural forms of dealing with pain and sickness are abandoned in order to put expectations in a particular technique.

The classic allusion made in the movie The Seventh Seal (1956) regarding our constant game of chess against Death, being that we all know who wins in the end, is made into a game where people expect to win. In this way, the old respect physicians and healers used to have for Charon and its ferry of the final crossing gives way to a technological hubris, an arrogance towards death in which the human body (foreign to itself) is just a mean. As Illich highlights, as such struggle happens, "the patient became a residual object, then a technological construct" (ILLICH, 1995, p. 1652). Aiming to maintain its institution, the medical corporation acts towards the formation of a set of beliefs that make its revision impossible at the expense of the patients' autonomy. The subject loses even his capacity to accept death.

Social iatrogenesis and structural iatrogenesis produced a moral and a legal apparatus that make small acts of individual autonomy impossible, such as: a) to declare oneself as ill; b) to refuse certain treatments; c) to use the drug of personal choice; d) to be treated by a person (and not only a professional) one chooses; and e) to be free to die undiagnosed. The eternal search for health, as an institutionalized technique, could be considered a disease on its own right. Such quest stops us from realizing some truths of the body: a) that we will never eliminate pain; b) that we will never cure all diseases; and c) that we will all die someday (ILLICH, 1994).

However, structural iatrogenesis is not derived, exactly, from the medicalization of life - but medicalization itself is derived from institutionalization, professionalization, mediation, and technological use. Living beings become a part of a coordinated system where they act according to roles. We take part in a population ecology in which the medical system is not only a diagnosis and treatment scheme but also a set of rules for "optimizing life." The Functional system, as a big coordinated and managed population, embodies life in all its aspects (ILLICH, 1995). The project of institution health is to transform, in the end, the body into information, that is, to disembody through dependency on medicalization. In the end, we become information in a sea of infinite memory. We are no longer mortal or immortal, but a-mortal, because we lose even the ability to die - or to live (ILLICH, 1974a). 


\section{The age of systems}

Chicago, 1964. Surrounded by the indefinite voices in an auditorium, preceding a speech that he would give to other professors, Ivan Illich was sitting by a table, chatting with a young anthropologist. In the apex of the conversation, the young man shot: "Illich, you're not able to involve me, you can't communicate with me!". Like many young university students of today, he was complaining of Ivan's lack of performativity. As he saw it, the professorial Illich should be able to catch his attention like a movie picture. After a moment of bewilderment, Illich was furious. The reason, he realized years later, was that then, for the first time in his life, somebody spoke to him as if he were a transponder. That is, a living person, with whom he thought to be in dialogue, considered his speech something a lot more impersonal, as if it were a cybernetic interface, incapable of creating alterity (ILLICH, 1990).

This cybernetics, a theme Illich approached in his later work, is visualized in a great social system that, through power tools, makes us all part of a tremendous and complex manipulative industrial set. The apex of this social heteronomization, which until then was done through institutions, starts to happen through a totalizing integrated social system.

This problematization proposed by Illich finds its core in the matters of the body, explored in his oeuvre from the 1990 s on. As some of his interpreters note, like Nogueira (2003), Illich starts to echo the notion of body found in the works of Michel Foucault. To Illich, the body is the locus of experience and, hence, is given in the relationship between flesh and its context. So, what we call body ("my body") is the body that is experienced. For instance, the current body, as a reflection of industrial society, is "freightable," transportable as a commodity, which would be an absurd conception for an inhabitant of previous centuries. "Engineering manuals speak of 'self-transportation' when we use our feet rather than the elevator. And we feel [...] deprived if we must fall back on our feet" (ILLICH, 1986, p. 1326). The actual body is the experienced body in the material conditions of its historical moment and place. In this manner, Illich goes from the argument of the iatrogenic body into one of the bodies that are manufactured by the social system to act in it. When he argued against the institutionalization of health, Illich (1975a) realized that the body was experienced as a result of clinical intervention, which he names the iatrogenic body. Even the denial of such an institution iatrogenizes the body: "two apples a day keeps the doctor away," goes the British saying, still popular nowadays.

Such an argument, put forward in his book "Medical Nemesis" of 1975, is confronted by a changing world. By the end of the 1980s, Illich realized that something was changing in the context of body production. From the body as a result of industry (iatrogenic body), the author notes that such medicine starts to be internalized, as industrial production itself. Like this, Illich argues that the body of the Western human is no longer iatrogenic, but produced by people themselves based on the systemic way of understanding the world.

The granting of the body to the health professional has given way to granting the body to a health neurosis. We internalize the professional and begin to embody the medical opinion into our everyday practices. We reify our own body, making it less of a concern to ourselves (assuming possible to do this). The same way our society is a reified manageable mass, we separate our body from our mind and start to manage it. Henceforth, the body is no longer reduced to be subject to medical interference, is no longer the iatrogenic body, but a manageable, manufacturable, shapeable body. "From an enterprise that objectifies people as bodies or psyches, a new model has sprung up that engenders people who objectify themselves: those who conceive of themselves as 'producers' of their bodies." (ILLICH, 1992, p. 217). Or else, we can notice: the body became, even in academic documents, from a "material" world into an "immaterial" world. This way, we have bodily work, now called material, and an "immaterial" work, that is just an absurd way to get the body out of focus and legitimize the reification and exploration of labor. In this process, we become systemic and cybernetic parts of a social body, internalizing the social functions in ourselves.

Such conceptualization reminds us of functionalist structuralism. On the one hand, everything has to be a part of a welldesigned and modeled scheme of reality - the formal structure. On the other hand, each piece of this structure has to have its function - as the body and its organs, where "the set of beliefs and feelings common to the mean of the members of a society forms a given system which has a life of its own," forms a "collective conscience," a social body (DURKHEIM, 1977, p. 50). 


\section{MASS SURVEILLANCE SUBJECTIVATION}

If we reify our bodies to favor a cohesive social system that seeks homeostasis through its professionalized social organs, the computer, the internet, and the most usual communication means are the ultimate forms of operating it. Illich's intuition was that ever since the 1980's a "cybernetic personality" was on the rise, which replaced the critique into a more radical position. As they integrate into a cybernetic text, the social institutions began to include people with a new correspondent mental space. So, the problem is not that school impedes instruction, but that its existence denotes a system in which social segregation became necessary. Hence, the belief in the need to be instructed is nothing more than the consequence of the required means to socialization (ILLICH, 1990, p. 18).

With cybernetic personality, the separation between user and tool ${ }^{8}$ is lost, and we begin to control ourselves. What could resemble a utopia is the formation of a police-like total subjectivity reaching levels that not long ago were unimaginable, as Samerski $(2018$, p. 18) points out:

Yet, with the rise of a new governmental regime centered around "security", as well as with refined statistical techniques and automated computational power, citizens have increasingly come to be treated as statistical cases, as faceless risk profiles. People are not governed in relation to their individuality or identity but as members of populations. That embodied individual is of interest to governments insofar as the individual.

To feel safe, the inhabitants of the body of cybernetic personality have a constant need for surveillance and control. They can no longer trust their senses and embody, literally, the necessity of self-surveillance and control. In a second moment, everyone becomes suspects (SAMERSKI, 2018).

This brings back to the fore the idea of managerial fascism found in the first texts of Illich from the 1970s. It is the idea of internalization, through cooptation or the kidnapping of the individuals' subjectivities, the values and ideals of the company and its members, namely, of maximization of efficiency and maintenance of safety and order. In this sense, the jogging apps, the online publications of visits to certain places (through "check-ins," "stories," and different social media posts) and other ways of reporting personal life strengthen mutual control and quantify lives to the point of achieving omnipresence of competition and of the conception of risk, which leads to burnout, fear, anxiety, and depression.

\section{FINAL REMARKS}

The present paper starts by introducing the concept of institutional imbalance and how it is derived from an analytical category based on Ivan Illich's idea of tool. For the author, they are separated between hand and power tools. The first ones are those where all the energy required for their usage come from their users. The second ones are the tools that use energy external to the human being, at least partially. If the auger can illustrate the first one, the second one would be the drilling machine. The more complex the power tool repertoire becomes, the bigger the tendency that the tools become a black box, which excludes the possibility of becoming and of creative action.

So, after certain watershed is passed, the set of power tools captures the hand tools. With that, the "kingdom of manipulations" is opened, where tools become manipulative, where the user-tool relation is inverted: the human, and not the tool, becomes the mean to achieve an end.

The framework of tools is, in Illich's thought, what composes the core of institutions. Once it becomes manipulative, the institution's raison d'être becomes a tautological legitimation. From this point on, we trace the path of the critique of institutionalization and its progressive intensification, which culminates in a structural change of society. A transformation of the set of institutions into a huge cybernetic machine occurs.

\footnotetext{
${ }^{8}$ The separation between user and tool amounts to a central concept to Ivan Illich. It is called "distality," which arises with the Age of Tools (by the end of the Middle Ages), and that allows for a technique to be used to a user's advantage.
} 
In other words, we present how the Age of Tools became the Age of Systems through institutions. Illich's classic works of the 1970s, that focus on specific institutions (school, work, and health), constitute what the author called "system" in his later work. One consequence of the process is that the iatrogenic body, dependent on the medical institution, becomes the cybernetic body, completely disembodied. This body, our body, is a functioning part of the body with organs, which is functionalist, which makes an Age of Systems possible.

In the fourth chapter, we go on to illustrate the cybernetic problem. To do so, we address how the mass surveillance systems, so present nowadays, derive from the mental topography of the Age of Systems. In this sense, the Age of Systems is the historical moment in which we find ourselves. It is when the predominance of manipulative tools deepens through the integration of institutions. We become sub-systems of the social system, life becomes an immune system, and the planet itself is seen as an ecosystem. We introject the roles we perform in the system full time. We become Tiqqun's (2010) Bloom, a non-being, a potpourri of roles to be performed, of system-coopted subjectivity. But Illich's thought allows for a range of reflections and applications, in a way that we limited ourselves to discuss only one of them.

As Agamben (2013a, p. 9) highlights, in all of Illich's researches is present the notion of a threat to what characterizes the human. Such threat is visualized as the modern project of making every being into a needed one, into Illich's homo miserabilis. Opposing that, Illich intended, was the formation of a convivial society based on a skillful, autonomous, situational man that combines the predominance of hand tools with the common use of the environment, through the commons. Conviviality, in this sense, is not merely an organizational proposition: it reflects a project of society through a proposition of human being.

We can find other rich contemporary reflections that dialogue directly with Illich's oeuvre, especially in the work of Giorgio Agamben. The Italian philosopher recovers the idea of the Age of Tools in his archaeology of duty (AGAMBEN, 2015a). He also visualizes, based on the meaning Illich (ILLICH apud CAYLEY, 2005) attributes to the theological concept of mysterium iniquitatis, the institutionalization of the Catholic Church as the cornerstone of the modern State and of the current time of crisis (AGAMBEN, 2015b, 2013a). Agamben's other works include Illichian notions to elaborate upon the constitution of zoé as political life (2017), think of the necessity of a destituent power (2014) and towards minor biopolitics (2016).

Illich has been noted as a relevant author and in increasing use. It seems to us what Friedrich Nietzsche called a "posthumous author": his thoughts would only be appreciated after the time of his life. Ever since his death in 2002, Illich's theory has reached several movements, also being used in the field of organization studies. Pansera and Rizzi (2018) make use of Illich's work to think of how social cooperatives can constitute post-capitalist visions. Vieta (2014) works with Illich's thought along with Murray Bookchin's and Herbert Marcuse's to deepen the works of Proudhon (1989) and Mikhail Bakunin to prefigure organizations. Bialski, Derwanz, Otto et al. (2015) show how Illich was relevant to the constitution of the Degrowth debate. Swann (2018) affirms that Illich's thought was constitutive to the current critique of the Critical Management Studies movement. Martin Parker (2018) echoes Illich's critiques relating to the university (DUNNE, HARNEY, PARKER et al., 2008) and, in particular, to management schools. Armstrong (2013), for his part, uses the idea of disabling professions to study consumption. In Brazil, some contributions have been made, for instance, those of Daher and Seifert (2017), Leão Neto (2017), Leonídio and Leão Neto (2019), Casagrande (2018) and Freitas (2019). In Singh (2017), we can notice a question beyond what was discussed in the present article, bringing Illich's idea of commons to mull over convivial life. Reichel (2017) uses Illichean thought to think of organizations in a post-growth world. In fact, the same author, in the following year, signs a call of Organization journal, bolstered by Illich's thought, to think of a post-growth society (BANERJEE, JERMIER, PEREDO et al., 2018).

The first decades of the 21st century have already made clear that new and enormous challenges are ahead of us, such as climate change, authoritarianism, and social inequality. As we understand it, reading Ivan Illich shows great potential for the coming years and the author's thought allows for a constitution of a research agenda that addresses, for example: a) relations between technology, society and organizations; b) organizations in surveillance and risk societies; c) Degrowth; and d) alternative ways of organizing from the notion of conviviality. 


\section{REFERENCES}

AGAMBEN, G. Introduzione. In: ILLICH, I. Gender. Per Una Critica Storica Dell'Ugualianza. Vicenza: Neri Pozza, 2013a.

AGAMBEN, G. Por uma teoria do poder destituinte. Atenas: Instituto, 2014. Available at: <https://5dias.wordpress.com/2014/02/11/poruma-teoria-do-poder-destituinte-de-giorgio-agamben/>. Accessed on: Oct. 07, 2018.

AGAMBEN, G. Opus dei: Arqueologia do ofício [Homo Sacer, II, 5]. São Paulo: Boitempo Editorial, 2015a.

AGAMBEN, G. O Mistério do Mal: Bento XVI e o fim dos tempos. 1. ed. São Paulo: Boitempo; Florianópolis: Ed. da UFSC, 2015b.

AGAMBEN, G. Uma Biopolítica Menor. São Paulo: N-1 Edições, 2016.

AGAMBEN, G. O Uso dos Corpos [Homo Sacer, IV, 2]. São Paulo: Boitempo Editorial, 2017.

ARMSTRONG, P. Alienated consumption, the commodification of taste and disabling professionalism. Ephemera: Theory and Politics in Organization, v. 13, n. 2, p. 269-292, 2013.

BANERJEE, B. et al. Call for papers for a special issue of Organization: theoretical perspectives on organizations and organizing in a postgrowth era. Organization. 2018. Available at: <https://journals. sagepub.com/pb-assets/cmscontent/ORG/SI\%200rganization $\% 20$ Degrowth\%20(2).pdf>. Accessed on: Nov. 27, 2018.

$B E Y, H$. Fé midiática de fim de século. In: BEY, H. Sobre a anarquia. Porto Alegre: Deriva, 2008. p. 27-41.

BIALSKI, P. et al. 'Saving' the city: collective low-budget organising and urban practice. Ephemera: Theory and Politics in Organization, v. 15, n. 1, p. 1-19, 2015.

CASAGRANDE, L. O Poliencantamento do Mundo por meio das Organizações Imediatistas. 151f. 2018. Tese (Doutorado em Administração) - Escola de Administração, Programa de PósGraduação em Administração, Universidade Federal do Rio Grande do Sul, Porto Alegre, 2018.

CAYLEY, David (Ed.). The Rivers North of the Future: The Testament of Ivan Illich as told to David Cayley. Toronto: House Of Anansi Press, 2005.

CODELLO, F. "A Boa Educação": Experiências Libertárias e Teorias Anarquistas na Europa, de Godwin a Neill. Vol. 1: A Teoria. São Paulo: Imaginário, Ícone, 2007.

COOKE, B. The managing of the (third) world. Organization, v. 11, n. 5, p. 603-629, 2004.

DAHER, S.; SEIFERT, R. E. Gênero em organizações convivenciais: possibilidades de um espaço de redistribuição, reconhecimento e representação. In: COLÓQUIO INTERNACIONAL DE EPISTEMOLOGIA E SOCIOLOGIA DA CIÊNCIA DA ADMINISTRAÇÃO, 6., 2017, Florianópolis. Anais... Florianópolis: Universidade Federal de Santa Catarina, 2017. DEBORD, G. Manifesto internacional situacionista. 2011. Available at: <https://pt.protopia.at/wiki/Manifesto_Internacional_Situacionista>. Accessed on: Apr. 12, 2015.

DUNNE, S. et al. Discussing the role of the business school. Ephemera: Theory and Politics in Organization, v. 8, n. 3, p. 271-293, 2008.
DURKHEIM, E. Da divisão do trabalho social. São Paulo: Martins Fontes, 1977

ESTIMADO, R. B.; SANTOS, J. L. L. P. Limites e possibilidades da educação formal: um debate entre Paulo Freire e Ivan Illich. Humanidades em Diálogo, n. 6, p. 175-190, 2014.

FAURE, S. A Colmeia: Uma Experiência Pedagógica. São Paulo: Biblioteca Terra Livre, 2015.

FREIRE, P. Apresentação. In: HARPER, B. et al. Cuidado, escola! Desigualdade, domesticação e algumas saídas. São Paulo: Brasiliense, 1980. p. 7.

FREIRE, P. Pedagogia do oprimido. 17. ed. Rio de Janeiro: Paz e Terra, 1987.

FREITAS, N.C. Ferramentas Organizacionais da Convivialidade: Aproximações de Ivan Illich aos Estudos Organizacionais. 106 f. 2019. Dissertação (Mestrado em Administração) - Escola de Administração, Programa de Pós-Graduação em Administração, Universidade Federal do Rio Grande do Sul, Porto Alegre, 2019.

GRAEBER, D. Bullshit jobs: a theory. London: Simon \& Schuster, 2018.

GUERREIRO RAMOS, A. A nova ciência das organizações. 2. ed. Rio de Janeiro: Fundação Getúlio Vargas, 1989.

ILLICH, I. Tools for conviviality. New York: Harper \& Row, 1973a.

ILLICH, I. La convivialité. Paris: Seuil, 1973b.

ILLICH, I. Medical nemesis. The Lancet, v. 303, n. 7863, p. 918-921, 1974a.

ILLICH, I. La convivencialidad. Barcelona: Barral, 1974b.

ILLICH, I. La convivialità. Milano: Arnoldo Mondadori, 1974c.

ILLICH, I. A Expropriação da Saúde: Nêmesis da Medicina. Rio de Janeiro, Nova Fronteira, 1975a.

ILLICH, I. Escola, esta vaca sagrada. In: ILLICH, I. Celebração da consciência. Petrópolis, RJ: Vozes, 1975b.

ILLICH, I. Vigor sexual e poder político. In: ILLICH, I. Celebração da consciência. Petrópolis, RJ: Vozes, 1975c.

ILLICH, I. A Convivencialidade. Lisboa: Publicações Europa-América, 1976.

ILLICH, I. Disabling professions (ideas in progress). London: Marion Boyars, 1977a.

ILLICH, I. Outwitting developed nations. In: ILLICH, I. Toward a history of needs. Berkeley, CA: Heydey, 1977b.

ILLICH, I. Body history. The Lancet, v. 328, n. 8519, p. 1325-1327, 1986.

ILLICH, I. Na ilha do alfabeto. In: ILLICH, I. Educação e liberdade. São Paulo: Imaginário, 1990. p. 21.

ILLICH, I. Twelve years after medical nemesis. In the mirror of the past, lectures and addresses, 1978-1990. New York: Marion Boyars, 1992.

ILLICH, I. Health as one's own responsibility: no, thank you! Journal of Consciousness Studies, v. 1, n. 1, p. 25-31, 1994. 
ILLICH, I. Death undefeated: from medicine to medicalisation to systematisation. British Medical Journal, v. 311, n. 7021, p. 16521653, 1995.

ILLICH, I. Necessidades. In: SACHS, W. (Ed.). Diccionário del desarollo: un guía del conocimiento como poder. Lima: Pratec, 1996. p. 144-163.

ILLICH, I. Energia e equidade. In: LUDD, N. (Org.). Apocalipse motorizado: a tirania do automóvel em um planeta poluído. São Paulo: Conrad, 2005. p. 33-72.

ILLICH, I. Sociedade desescolarizada. Porto Alegre: Deriva, 2007.

ILLICH, I. Sociedade sem escolas. Petrópolis, RJ: Vozes, 2018.

ILLICH et al. Educação e Liberdade. São Paulo: Imaginário, 1990.

LATOUCHE, S. Será o decrescimento a boa nova de Ivan Illich? São Leopoldo, RS: Instituto Humanitas Unisinos, 2012. (Cadernos IHU Ideias, ano 10, n. 164).

LEÃO NETO, E. P. S. Ivan Illich: uma aproximação com sua trajetóriaobra (1926-1967). 117 f. 2017. Master Thesis (Master Degree in Applied Ecology) - Ecologia de Agroecossistemas, Universidade de São Paulo, Piracicaba, 2017.

LEONIDIO, A., LEÃO NETO, E. P. S. A Utopia de Ivan Illich. Diálogos Latinoamericanos, v. 20, p. 30-40, 2019.

MARCUSE, H. One-dimensional man: studies in the ideology of advanced industrial society. 2. ed. Boston: Beacon Press, 1991.

MARSDEN, R.; TOWNLEY, B. Introdução: a coruja de Minerva - reflexões sobre a teoria na prática. In: CLEGG, S. R.; HARDY, C.; NORD, W. R. (Orgs.). Handbook de estudos organizacionais. São Paulo: Atlas, 2001. v. 2, p. 31-60.

MESQUIDA, P. O diálogo de Illich e Freire em torno da educação para uma nova sociedade. Contrapontos, v. 7, n. 3, p. 549-563, 2007.

MILANA, F. Ivan Illich, cronologia della vita. In: ILLICH, I. Pervertimento del cristianesimo. Macerata: Quodlibet, 2008. p. 123-148.

NOGUEIRA, R. P. A segunda crítica social da saúde de Ivan Illich. Interface: Comunicação, Saúde, Educação, v. 7, n. 12, p. 185-190, 2003.

ORWELL, G. 1984. São Paulo: Claro Enigma, 2010.

O SÉTIMO selo. Direção: Ingmar Bergman. Estocolmo: Svensk Filmindustri, 1956. 1 DVD (96 min), son., P\&B.
PANSERA, M.; RIZZI, F. Furbish or perish: Italian social cooperatives at a crossroads. Organization, p. 1-19, 2018. Available at: <https:// doi.org/10.1177/1350508418760980>. Accessed on: Apr. 12, 2015.

PARKER, M. Shut down the business school. Chicago: University of Chicago Press, 2018.

PROUDHON, P.-J. General idea of the revolution in the nineteenth century. London: Freedom Press, 1989.

REICHEL, A. Shape of things to come: from the 'laws of form' to management in the post-growth economy. Ephemera: Theory \& Politics in Organization, v. 17, n. 1, p. 89-118, 2017.

SAMERSKI, S. Individuals on alert: digital epidemiology and the individualization of surveillance. Life Sciences, Society and Policy, v. 14, n. 1, p. 13, 2018.

SER E VIR A SER. Produção de Clara Belar. Realização de Clara Belar. Roteiro: Clara Belar. [s.I]: Pourquoi Pas Productions, 2015. (99 min.), DVD, son., color. Legendado.

SILVA, G. C. E. A polêmica Paulo Freire e Ivan Illich: notas sobre educação e transformação. Revista Sul-Americana de Filosofia e Educação, n. 24, p. 102-120, 2016.

SINGH, N. Becoming a commoner: the commons as sites for affective socio-nature encounters and co-becomings. Ephemera: Theory \& Politics In Organization, v. 17, n. 4, p. 751-776, 2017.

SWANN, T. Towards an anarchist cybernetics: Stafford Beer, selforganisation and radical social movements. Ephemera: Theory and Politics in Organization, v. 18, n. 3, p. 427-456, 2018.

TIQQUN. Bloom Theory. 2018. Available at: <https://theanarchistlibrary. org/library/tiqqun-bloom-theory>. Accessed on: July 20, 2018.

TRAGTENBERG, M. A delinquência acadêmica. Verve: Revista Semestral Autogestionária do Nu-Sol, n. 2, p. 175-184, 2002.

ULTRAFARMA. Ultrafarma com Dunga e Gilmar Rinaldi. 2018. Available at: <https://www.youtube.com/watch?v=9qNE305VmQE >. Accessed on: Dec. 11, 2018.

VIETA, M. The stream of self-determination and autogestión: prefiguring alternative economic realities. Ephemera: Theory and Politics in Organization, v. 14, n. 4, p. 781-809, 2014.

Lucas Casagrande

ORCID: https://orcid.org/0000-0002-8327-4810

PhD in Organization Studies at Federal University of Rio Grande do Sul (PPGA-UFRGS); Professor at Management School of Federal University of Rio Grande do Sul (EA-UFRGS), Porto Alegre-RS, Brazil.E-mail: lucas.casagrande@ufrgs.br

Nilo Coradini de Freitas

ORCID: https://orcid.org/0000-0002-2327-8297

Master of Science in Organization Studies at Federal University of Rio Grande do Sul (PPGA-UFRGS), Porto Alegre - RS, Brazil. E-mail: nilof@tutanota.com 